\title{
Meiotic Arrest Compromises Pollen Fertility in an Interspecific Hybrid between Brachiaria ruziziensis $\mathbf{x}$ Brachiaria decumbens (Poaceae: Paniceae)
}

\author{
Andréa Beatriz Mendes-Bonato ${ }^{1}$, Maria Suely Pagliarini ${ }^{1 *}$, and Cacilda Borges do Valle ${ }^{2}$ \\ ${ }^{1}$ Department of Cell Biology and Genetics; State University of Maringá; mspagliarini@uem.br; 87020-900; \\ Maringá - PR - Brasil; ${ }^{2}$ Embrapa Beef Cattle; cacilda@cnpgc.embrapa.br; P.O. Box 154; 79002-970; Campo \\ Grande - MS - Brasil.
}

\begin{abstract}
Microsporogenesis was analyzed in an interspecific hybrid between an artificially tetraploidized sexual accession of Brachiaria ruziziensis $(2 n=4 x=36)$ and a natural apomictic tetraploid accession of $\mathrm{B}$. decumbens. Syncytes involving a large number of cells were recorded in 15.4\% of meiocytes. Meiosis progressed normally in syncytes during prophase I; in metaphase I, however, several nuclei were found fusioned, showing chromosome stickiness and several chromosome fragments. Meiosis was arrested in metaphase I and pycnotic nuclei and micronuclei were formed. Abnormal cytokinesis fractionated the syncyte into abnormal meiotic products that were covered by the pollen wall. Meiocytes in leptotene were recorded in all the slides prepared for both meiotic divisions, and abnormal "pollen grains" with well-developed pollen wall but containing leptotene nuclei were recorded in $9.18 \%$ of grains analyzed. These findings suggested that the meiocytes received the signal to enter meiosis but lacked the signal to proceed beyond leptotene. Despite the absence of the meiotic process, such cells were covered by pollen grain wall. Total pollen sterility resulted from these abnormalities combined with still others observed among meiocytes.
\end{abstract}

Key words: Brachiaria decumbens, Brachiaria ruziziensis, cell fusion, interspecific hybrid, meiosis arrest, pollen sterilitiy

\section{INTRODUCTION}

A large number of genetically controlled physiological, biochemical and morphological processes within the flower are involved in the production of fertile pollen. Any disruption during development of stamens, differentiation of the sporogenous cells, meiosis, development of the free microspores, microspore mitosis, pollen differentiation or anthesis can result in male-sterile plants (Glover et al., 1998). Kaul (1988) described several examples in plants where meiosis proved to be the developmental step most sensitive to disruption with the majority of male-sterile mutants acting either at the beginning or end of meiosis. Male-sterile mutants presenting defects in one or more stages have been reported in many different plant species. An understanding of the meiotic process is pivotal to furthering research on reproduction, fertility, genetics and breeding and, in higher plants, has serious implications in crop production (Armstrong and Jones, 2003), especially if the grain is desired.

Author for correspondence 
Native to the African tropical savannas, some species of the genus Brachiaria have become the most important pasture cultivars in the American tropics due to good adaptation to extended dry period, and to acid soils. In the Brazilian savannas, two polyploid $(2 n=4 x=36)$ and apomictic cultivars are widespread over millions of hectares maintaining reasonable nutritive value thus yielding good animal production but both display some limiting characteristics and represent an environmental/economic risk due to the monoculture imposed. Developing new cultivars to increase genetic diversity using more efficient methods to assess edaphic adaptation, resistance to pests and good nutritive values is of particular concern in Brachiaria breeding programs. To date, the potential of apomictic reproduction is becoming better appreciated, and cross-compatible sexual genotypes are being identified or produced. Artificial hybridization in the Brazilian Brachiaria breeding program had been initiated in 1988, when a germoplasm collection containing 475 accessions of 15 species was introduced in the Embrapa Beef Cattle Research Center (Embrapa Gado de Corte) from Centro Internacional de Agricultura Tropical (CIAT/Colombia).

For a new cultivar to be successfully adopted, it has to combine high forage yield, nutritive value, resistance to pests and diseases, and good seed production. Therefore, fertile pollen grains are required for effective pollination, seed set and development. In this context, several interspecific hybrids produced at Embrapa Gado de Corte trying to combine several desirable characteristics are under agronomical and cytological evaluation. The aim of this work was to study some meiotic abnormalities that impaired pollen fertility in a hybrid between B. ruziziensis x B. decumbens.

\section{MATERIAL AND METHODS}

Cytological studies were carried out on the interspecific hybrid, whose female genitor was an artificially tetraploidized sexual accession of $B$. ruziziensis $(2 \mathrm{n}=4 \mathrm{x}=36)$ and the male genitor was the most common cultivar of $B$. decumbens, cv Basilisk, a natural tetraploid apomictic $(2 n=4 x=36)$. The hybrid was a product of the Brachiaria breeding program in progress at Embrapa Beef Cattle (Campo Grande, state of Mato Grosso do Sul, Brazil) and was under agronomic evaluation.
Inflorescences for microsporogenesis studies were collected and fixed in a mixture of ethanol (95\%), chloroform and propionic acid (6:3:2 v/v) during $24 \mathrm{~h}$. Microsporocytes were prepared by squashing and stained with $0.5 \%$ propionic carmine. Pollen fertility was estimated using Alexander reactive (Alexander, 1969).

\section{RESULTS}

A total of 2174 meiocytes and 2426 pollen grains were analyzed in the hybrid. Because of its interspecific and polyploid condition $(2 \mathrm{x}=4 \mathrm{x}=$ 36 ), a great number of meiocytes presented irregular chromosome segregation in both meiotic division and the totality of observed tetrads showed from one to several micronuclei in each microspore. Furthermore, this hybrid showed fusions involving $15.40 \%$ of meiocytes. In some syncytes, more than one hundred meiocytes in the same divisional phase was recorded (Fig. 1a). Despite of cell fusion, meiosis progressed normally in prophase I (Fig. 1b), but in several cases, fusion of nuclei was also observed, leading to the formation of polyploid nuclei (Fig. $1 \mathrm{~b}$ to $\mathrm{g}$ ). Fig. 1c showed a syncyte where several nuclei were fusioned and an enormous amount of cytoplasm remained anucleated. In metaphase I, a large number of fragments (Fig. 1d, e) and chromosome stickiness involving tetraploid and higher ploidy nuclei were also found (Fig. 1f, g). These abnormalities interrupted meiosis in metaphase I and, as a consequence, the formation of pycnotic nuclei and micronuclei (Fig. 1h) occurred. Abnormal cytokinesis occurred in the syncytes and meiotic products containing different numbers of nuclei and micronuclei were formed (Fig. 1h). Anucleate, uninucleate and multinucleate pollen grains of different sizes were observed (Fig, 1i, j).

Among pollen grains analyzed, $9.18 \%$ presented cell shape and cell wall typical for its specific developmental stage, but the nucleus was typical of prophase I (leptotene) showing that meiocytes entered meiosis but did not proceed (see Fig. 2a to d). Indeed, meiocytes with prophase nucleus were recorded in all slides prepared for both meiotic divisions. Multinucleate pollen grains resulting from cell fusion were also recorded during analysis (Fig. 2d, e). Pollen sterility was complete. 


\section{DISCUSSION}

Recent cytological studies in the genus Brachiaria have shown different kinds of abnormalities, including those affecting the meiotic stages (Mendes-Bonato et al., 2001a b c, 2002a b; Risso-
Pascotto et al., 2002, 2003a b; Mendes-Vieira et al., 2005; Mendes-Bonato et al., 2006) as well as the postmeiotic ones (Junqueira Filho et al., 2003; Mendes-Bonato et al., 2004; Risso-Pascotto et al., 2005a).

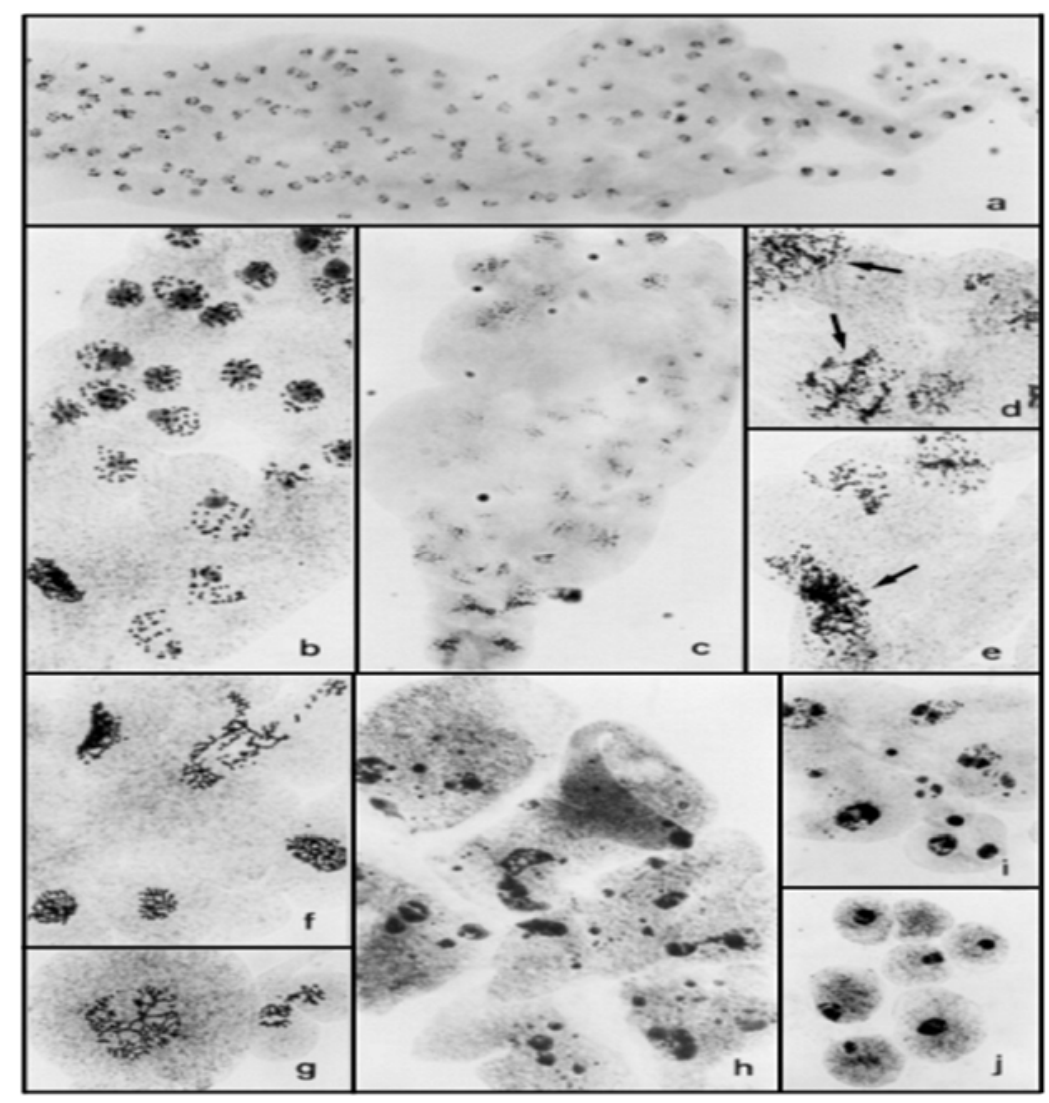

Figure 1 - General aspects of syncytes. a - c) Syncyte with leptotene nuclei (a), diaki1 metaphase I (c). d, e) Metaphase I with some polyploid nuclei (arrow) side the normal tetraploid ones. In both, several chromosome fragments can be g) Chromosome stickiness also involving several genomes. h) Several py after irregular cytokinesis in the syncyte. $\mathrm{i}, \mathrm{j}$ ) Abnormal meiotic products $\mathrm{r}$ nuclei of different sizes

Cell fusion involving no more than ten cells was reported in B. decumbens (Mendes-Bonato et al., 2001 a), B. brizantha (Mendes-Bonato et al., 2001b; Risso-Pascotto et al., 2003a), and $B$. humidicola (Boldrini et al., 2006). In all these cases, the nuclei maintained their integrity and, as a consequence, fusion of nuclei was not recorded. In the present hybrid, however, cell fusion involved a large number of meiocytes and fusion of nuclei was frequent.
Chromosome stickiness was also reported in syncytes of $B$. decumbens (Mendes-Bonato et al., 2001a) but not with the intensity found in this hybrid. Although chromosome stickiness has been widely reported among plants (see MendesBonato et al., 2001c), and many factors have been suggested as the cause, the primary cause and the biochemical basis of this abnormality are still unknown. Gaulden (1987) hypothesized that chromosome stickiness may result from deficient 
or defective functioning of one or two types of non-histone chromosomal proteins. The phenotypic manifestation of stickiness may be highly variable. In the severe cases, such as found in the present hybrid, the fusion of all chromosomes into a single amorphous mass impaired chromosome segregation. In these cases, stickiness is generally associated with chromosome breakage and acentric fragments remain in the cytoplasm (Dowd et al., 1986). In extreme cases of stickiness, the impossibility of chromosome segregation prompts the formation of single or varying numbers of pycnotic nuclei that could culminate in full chromatin degeneration.

The other abnormality found in this hybrid has never been reported before either for Brachiaria or for other plant species. The occurrence of meiocytes in leptotene during the meiotic course showed that some cells received the signal to enter meiosis but lacked the signal to proceed. Despite the absence of meiosis, such cells were covered by pollen grain wall. Microsporogenesis and megasporogenesis comprise three sequential, but distinct stages that culminate in gamete production. These stages, premeiosis, meiosis and postmeiosis, are controlled and coordinated by a variety of genes that act individually, suggesting an independent hierarchic gene control at each step (Golubovskaya, 1979, 1989). The occurrence of "pollen grains" containing prophase meiotic nuclei indicates that when the tapetal cells are triggered to synthesize pollen grain walls, all cells are covered by them whether they have undergone meiosis or not. This phenomenon reinforces the assumption of independence between genetic control of meiotic and posmeiotic stages.

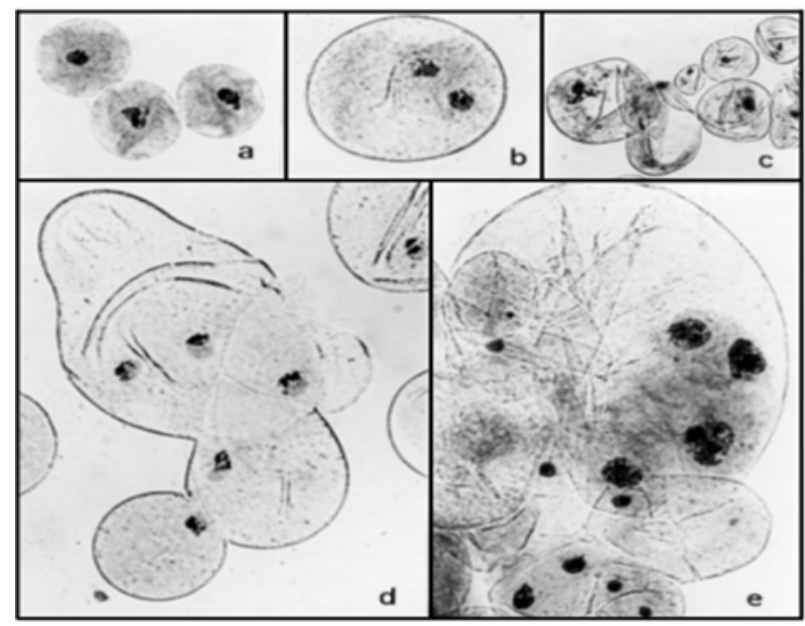

Figure 2 - Abnormal "pollen grain". a) "Pollen grains" with leptotene nucleus. b "pollen grain" with leptotene nuclei. c) Abnormal pollen grains of differ content of chromatin. d) Anomalous "pollen grain" with five leptoter Anomalous pollen grain with pycnotic nuclei

The role of individual meiotic genes in initiating meiosis in higher plants is an intriguing problem. It may be viewed as requiring an understanding of two gene regulatory processes: the first switches the cell from the mitotic cell cycle to embark upon meiosis. The second causes the meiocyte to enter into meiotic prophase I and to proceed with chromosome synapsis and the subsequent events that characterize meiosis (Golubovskaya, 1989; Murray, 1992). It is likely that the former process occurs in the $G_{1}$ phase of the cell cycle while the latter process must occur no later than during the $\mathrm{G}_{2}$ phase (Golubovskaya et al., 1993).

The initiation of meiosis has been extensively reviewed in maize. One mutation, ameiotic (aml), originally reported by Palmer (1971), allowed 
some studies of the differences between meiotic and mitotic cell division (Staiger and Cande, 1992; Golubovskaya et al., 1993, 1997). In this mutant, the last premeiotic mitosis proceeded normally; however, meiosis did not occur. Instead, at stages when one would expect a meiotic division based on anther size, ameiotic plants underwent a synchronized mitotic division. Considering that the ameiotic mutation disturbed developmental events earlier than any other meiotic mutations, mutations were induced by nitroso-N-methylurea and from active Robertson's mutator stock and several double meiotic mutants were constructed by Golubovskaya et al. (1993) to study the interaction of genes in the progression of meiosis. A new allele of the aml (praI-prophase I arrest), designated am1-pra I, and a new meiotic mutant, lar*-487 (leptotene arrest $*-487$ ), affecting meiosis initiation were obtained. Both presented phenotypic expressions very similar to those recorded in this Brachiaria hybrid. In the am1-pra I mutant, meiocytes entered meiosis but the progression was arrested at early prophase I; chromatin and cell degradation occurred following early prophase I, including the formation of a syncyte containing numerous prophase I nuclei; pycnotic nuclei and lysis of chromatin were observed in the syncytes; and multinucleate cells were also often formed in this mutant. In the lar487 mutant, the phenotype was similar, but could be distinguished from the previous since plants grown in the greenhouse displayed severe pollen sterility: most of the pollen mother cells had meiosis arrested at the leptotene stage, all nuclei were in a commom syncyte and soon degenerated. Only a few nuclei progressed into the later stages of meiosis but also degraded. In plants grown in the field, the same meiotic phenotype was observed, but the expression was not as severe and some cells continued meiosis as far as the pachytene stage.

The abnormality found in this interspecific hybrid occurred spontaneously and perhaps was caused by mutation. Its phenotypic expression was very similar to the am 1-praI and lar*-487 mutations of maize, also including the abnormal process of envelope formation around extremely abnormal microspores. The am1-praI and lar*-487 caused complete male sterility in maize (Golubovskaya et al., 1993). In this case, although this abnormality affected only $15.40 \%$ of the meiocytes in the hybrid, pollen sterility was total. Other meiotic abnormalities, including a high frequency of irregular chromosome segregation leading to unbalanced gamete formation and abnormal pollen mitosis have also contributed (Mendes-Bonato et al., 2004). The intra- and interspecific crosses in the Brachiaria breeding program aim at producing superior hybrids but for these to impact animal production systems high seed production is essential. Thus, hybrids displaying these types of problems need to be identified and discarded early in the process to avoid contributing defective genes to the gene pool.

Artificial hybridization in Brachiaria has been sought at least since the early 1970s when Ferguson and Crowder (1974) attempted to produce hybrids by pollinating diploid sexual $B$. ruziziensis with pollen from a tetraploid apomictic $B$. decumbens. This attempt was unsuccessful due to the ploidy barrier. Brachiaria hybridization became possible only in the early 1980 s, when Swenne et al. (1981) developed an obligately sexual tetraploid $B$. ruziziensis by colchicine treatment. Hybridization with the newly available sexual tetraploid was then begun by Ndikumana (1985) that crossed this material with tetraploid apomictic accession of $B$. decumbens or $B$. brizantha as pollinators. The resulting population of hybrids was constituted by 35 individuals and the cause of low efficiency was not demonstrated. A new attempt for hybridization in Brachiaria was done by Lutts et al. (1991) crossed again $B$. ruziziensis with $B$. decumbens and $B$. brizantha. Based on hybrid seed set and viability of hybrid seedlings and chromosome pairing of hybrids, they found that $B$. ruziziensis was more closely related to $B$. decumbens than to $B$. brizantha. Meiotic behavior of hybrids led Lutts et al. (1991) to suggest that germplasm assigned to these three species formed a more or less coherent gene pool, once ploidy barriers were overcome. Only meiotic abnormalities related to irregular chromosome segregation due polyploidy were reported in the hybrids.

Brachiaria hybrids resulting from crosses between $B$. ruziziensis $\mathrm{x}$ B. brizantha and B. ruziziensis $\mathrm{x} B$. decumbens synthesized at Embrapa Beef Cattle and under cytological analysis presented different types of meiotic abnormalities (unpublished data), with a wide predominance of irregular chromosome segregation due polyploidy. In two half-sib hybrids between $B$. ruziziensis and $B$. brizantha (Risso-Pascotto et al., 2005b), more than $65 \%$ of pollen grains were sterile due to irregular chromosome segregation, chromosome stickiness, 
and abnormal cytokinesis. In another hybrid between $B$. ruziziensis x $B$. brizantha, RissoPascotto et al. (2004) showed that asynchronous meiosis was the cause of pollen sterility.

Thus, it could be concluded that the cytological behavior during meiosis seemed to be accessionspecific. While different levels of sterility have been reported in some interspecific hybrid combinations, indicating species incompatibilities (Lutts et al., 1991; Valle et al., 1994), many interspecific crosses within this species complex have been successful (Miles et al., 2004). Studies underway in hybrids between this species complex have revealed that it is possible to select hybrids with high pollen fertility and high seed set among those existing at Embrapa Beef Cattle.

\section{RESUMO}

A microsporogênese de um híbrido interespecífico entre um acesso sexual tetraploidizado artificialmente de Brachiaria ruziziensis $(2 \mathrm{n}=4 \mathrm{x}=36)$ e um acesso apomítico tetraplóide natural de $B$. decumbens $(2 \mathrm{n}=4 \mathrm{x}=36)$ foi analisada. Sincícios envolvendo um grande número de células foram encontrados em $15,40 \%$ dos meiócitos. A meiose progrediu normalmente nos sincícios durante a prófase I; em metáfase I, todavia, muitos núcleos fundiram-se, mostrando ainda aderências cromossômicas e inúmeros fragmentos. O processo meiótico foi interrompido na metáfase I, quando a cromatina formou núcleos picnóticos. Citocineses anormais fracionaram os sincícios em produtos meióticos anômalos que foram recobertos pela parede do grão de pólen. Meiócitos em leptóteno também foram observados durante todo o processo meiótico e grãos de pólen anormais com parede de pólen bem desenvolvida, mas contendo núcleos leptotênicos, foram observados em 9,18\% dos grãos de pólen analisados. Os resultados sugerem que os meiócitos receberam o sinal para entrar em meiose, mas não receberam o sinal para prosseguir além do leptóteno. Apesar da ausência de processo meiótico completo, os meiócitos foram cobertos pela parede do grão de pólen. Estas anormalidades, combinadas com outras causadas pela poliploidia, resultaram em total esterilidade de pólen.

\section{REFERENCES}

Alexander, M. P. (1969), Differential stain of aborted and non aborted pollen. Stain Technol., 44,117-122.

Armstrong, S. J.; Jones, G. H. (2003), Meiotic cytology and chromosome behaviour in wild-type Arabidopsis thaliana. J. Exp. Bot., 54, 1-10.

Boldrini, K. R.; Pagliarini, M. S.; Valle, C. B. (2006), Cell fusion and cytomixis during microsporogenesis in Brachiaria humidicola (Poaceae). South Afric. J. Bot., 72, 478-481.

Dowd, M. A; Gaulden, M. E.; Proctor, B. L.; Seibert, G.B. (1986), Formaldehyde-induced acentric chromosome fragments and chromosome stickiness in Chortophaga neuroblasts. Environ. Mutagen., 8, 401-411.

Ferguson, J. E.; Crowder, L. V. (1974), Cytology and breeding behavior of Brachiaria ruziziensis Germain et Evrard. Crop Sci., 14, 893-895.

Gaulden, M. E. (1987), Hypothesis: some mutagens directly alter specific chromosomal proteins (DNA topoisomerase II and peripheral proteins) to produce chromosome stickiness, which causes chromosome aberrations. Mutagenesis 2, 357-365.

Glover, J.; Grelon, M.; Craig, S.; Chaudhury, A.; Dennis, E. (1998), Cloning and characterization of MS5 from Arabidopsis: a gene critical in male meiosis. Plant J., 15, 345-356.

Golubovskaya, I. N. (1979), Genetic control of meiosis. Int. Rev. Cytol., 58, 247-290.

Golubovskaya, I. N. (1989), Meiosis in maize: mei genes and conception of genetic control of meiosis. Adv. Genet., 26, 149-192.

Golubovskaya, I. N.; Alvakina, N.; Sheridan, W. F. (1997), New insights into the role of the maize ameiotic1 locus. Genetics, 147, 1339-1350.

Golubovskaya, I. N.; Grebennikova, Z. K.; Avalkina, N. A.; Sheridan, W. F. (1993), The role of ameiotic1 gene in the initiation of meiosis and in subsequent meiotic events in maize. Genetics, 135, 1151-1166

Junqueira Filho, R. G.,; Mendes-Bonato, A. B., Pagliarini, M. S., Bione, N. C. P.; Valle, C. B.; Penteado, M. I. O. (2003), Absence of microspore polarity, symmetric divisions and pollen cell fate in Brachiaria decumbens (Gramineae). Genome, 46, 8388.

Kaul, M. L. H. (1988), Male sterility in higher plants, Springer-Verlag, Berlin.

Lutts, S.; Ndikumana, J.; Louant, B. P. (1991), Fertility of Brachiaria ruziziensis in interspecific crosses with Brachiaria decumbens and Brachiaria brizantha: meiotic behavior, pollen viability and seed set. Euphytica, 57, 267-274. 
Mendes-Bonato, A. B.; Junqueira Filho, R. G.; Pagliarini M. S.; Valle, C. B.; Penteado, M. I. O. (2002b), Unusual cytological patterns of microsporogenesis in Brachiaria decumbens: abnormalities in spindle and defective cytokinesis causing precocious cellularization. Cell Biol. Int., 26, 641-646.

Mendes-Bonato, A. B.; Pagliarini M. S.; Forli, F.; Valle, C. B.; Penteado, M. I. O. (2002a), Chromosome numbers and microsporogenesis in Brachiaria brizantha (Gramineae). Euphytica, 125, 419-425.

Mendes-Bonato, A. B.; Pagliarini M. S.; Valle, C. B.; Penteado, M. I. O. (2001b), Archesporial syncytes restricted to male flowers in a hexaploid accession of Brachiaria brizantha (Hochst) Stapf (Gramineae). Nucleus, 44, 137-140.

Mendes-Bonato, A. B.; Pagliarini M. S.; Valle, C. B.; Penteado, M. I. O. (2001c), A severe case of chromosome stickiness in pollen mother cells of Brachiaria brizantha (Hochst) Stapf (Gramineae). Cytologia, 66, 287-291.

Mendes-Bonato, A. B.; Pagliarini, M. S.; Silva, N.; Valle, C. B. (2001a), Meiotic instability in invader plants of signal grass Brachiaria decumbens Stapf (Gramineae). Acta Scientiarum, 23, 619-625.

Mendes-Bonato, A. B.; Pagliarini, M. S.; Valle, C. (2006), Abnormal spindle orientation during microsporogenesis in an interspecific Brachiaria (Gramineae) hybrid. Genet. Mol. Biol., 29, 122-125.

Mendes-Bonato, A. B.; Pagliarini, M. S.; Valle, C. B.; Jank, L. (2004), Abnormal pollen mitoses (PM I and PM II) in an interspecific hybrid of Brachiaria ruziziensis and Brachiaria decumbens (Gramineae). J. Genet., 83, 279-283.

Mendes-Vieira, D.; Mendes-Bonato, A. B.; Pagliarini, M. S.; Valle, C. B. (2005), Abnormal meiotic behavior in Brachiaria brizantha (Poaceae) leading to microspore degeneration. Caryologia, 58, 396-402

Miles, J. W.; Valle, C. B.; Rao, I.; Euclides, V. P. B. (2004), Brachiaria grasses. In: Warm-season (C4) grasses. (Sollenberg L.; Burson, B. eds). Agronomy Monograph, 45. ASA-CSSA-SSSA, Madison, USA, pp 745-783.

Murray, A. W. (1992), Creative blocks: cell-cycle checkpoints and feedback controls. Nature, 359, 599604.
Ndikumana, J. (1985), Etude de l'hybridation entre espèces apomictiques et sexuées dans le genre Brachiaria. Ph.D. Thesis. Université Catholique de Louvain, Louvain-la-Neuve, Belgium. 210 p.

Palmer, R. G. (1971), Cytological studies of ameiotic and normal maize with reference to premeiotic pairing. Chromosoma, 35, 233-246.

Risso-Pascotto, C.; Pagliarini, M. S.; Valle, C. B. (2002), Abnormal nucleolar cycle in microsporogenesis of Brachiaria decumbens (Gramineae). Cytologia, 67, 355-360

Risso-Pascotto, C.; Pagliarini, M. S.; Valle, C. B. (2003 b), A mutation in the spindle checkpoint arresting meiosis II in Brachiaria ruziziensis. Genome, 46, 724-728.

Risso-Pascotto, C.; Pagliarini, M. S.; Valle, C. B. (2005b), Meiotic behavior in interspecific hybrids between Brachiaria ruziziensis and Brachiaria brizantha (Poaceae). Euphytica, 145, 155-159.

Risso-Pascotto, C.; Pagliarini, M. S.; Valle, C. B.; Jank, L. (2005a), Symmetric pollen mitosis I and suppression of pollen mitosis II prevent pollen development in Brachiaria jubata (Gramineae). Braz. J. Med. Biol. Res., 38, 1603-1608.

Risso-Pascotto, C.; Pagliarini, M. S.; Valle, C. B.; Jank, L. (2004), Asynchronous meiosis in an interspecific hybrid of Brachiaria ruziziensis and B. brizantha. Plant Cell Rep., 23, 304-310.

Risso-Pascotto, C.; Pagliarini, M. S.; Valle, C. B.; Mendes-Bonato, A. B. (2003a), Chromosome number and microsporogenesis in a pentaploid accession of Brachiaria brizantha (Gramineae). Plant Breed., 122, 136-140.

Staiger, C. J.; Cande, W.Z. (1992), Ameiotic, a gene that controls meiotic chromosome and cytoskeletal behavior in maize. Develop. Biol., 154, 226-230.

Sweene, A.; Louant, B. P.; Dujardin M. (1981), Induction par la colchicine de formes autotétraploides chez Brachiaria ruziziensis Germain et Evrard (Graminée). Agron. Trop., 36, 134-141.

Valle, C. B.; Glienke, C.; Leguizamon, G. O. C. (1994), Inheritance of apomixis in Brachiaria, a tropical forage grass. Apomixis Newsl., 7, 42-43.

Received: June 15, 2005; Revised: July 27, 2006; Accepted: April 18, 2007 